\title{
Topoisomerase IV, not gyrase, decatenates products of site-specific recombination in Escherichia coli
}

\author{
E. Lynn Zechiedrich, ${ }^{1,3}$ Arkady B. Khodursky, ${ }^{2}$ and Nicholas R. Cozzarelli ${ }^{1,4}$ \\ ${ }^{1}$ Department of Molecular and Cell Biology and \\ ${ }^{2}$ Graduate Group in Biophysics, University of California, Berkeley, California 94720-3204 USA
}

\begin{abstract}
DNA replication and recombination generate intertwined DNA intermediates that must be decatenated for chromosome segregation to occur. We showed recently that topoisomerase IV (topo IV) is the only important decatenase of DNA replication intermediates in bacteria. Earlier results, however, indicated that DNA gyrase has the primary role in unlinking the catenated products of site-specific recombination. To address this discordance, we constructed a set of isogenic strains that enabled us to inhibit selectively with the quinolone norfloxacin topo IV, gyrase, both enzymes, or neither enzyme in vivo. We obtained identical results for the decatenation of the products of two different site-specific recombination enzymes, phage $\lambda$ integrase and transposon Tn3 resolvase Norfloxacin blocked decatenation in wild-type strains, but had no effect in strains with drugresistance mutations in both gyrase and topo IV. When topo IV alone was inhibited, decatenation was almost completely blocked. If gyrase al one were inhibited, most of the catenanes were unlinked. We showed that topo IV is the primary decatenase in vivo and that this function is dependent on the level of DNA supercoiling. We conclude that the role of gyrase in decatenation is to introduce negative supercoils into DNA, which makes better substrates for topo IV. We also discovered that topo IV has an unexpectedly strong DNA relaxation activity that, together with gyrase and topo I, is able to set the supercoiling levels in Escherichia coli.
\end{abstract}

[Key Words: DN A supercoiling; quinolones; $\lambda$ integrase; Tn3 resolvase; topoi somerase I]

Received June 20, 1997; revised version accepted August 5, 1997.

Catenated DNA dimers are important intermediates of two major biological processes, DNA replication and recombination. T opoisomerases decatenate these intermediates, all owing segregation of daughter chromosomes at cell division (for review, see Bjornsti 1991; Osheroff et al. 1991; Ullsperger et al. 1995; Wang 1996). In Escherichia coli four topoisomerases have been identified (for review, see Wang 1991; Ullsperger et al. 1995). These enzymes alter DNA topology by passing intact DNA through either transi ent singl e-stranded breaks (type-1 topoisomerase) or double-stranded breaks (type-2 topoisomerase) in DNA. The type-2 enzymes, topoisomerase II (topo II; DN A gyrase) and topoisomerase IV (topo IV), are essential for cell viability (Kreuzer and Cozzarelli 1979; Orr et al. 1979; Filutowicz and Jonczyk 1983; Kato et al. 1988; Schmid 1990). The genes for the two topo IV subunits are parC, which is homologous to gyrA of gyrase, and parE, which is homologous to gyrB of gyrase (Kato et al. 1990; Luttinger et al. 1991; Springer and Schmid 1993).

\footnotetext{
${ }^{3}$ Present address: Department of Microbiology and Immunology, Baylor College of Medicine, Houston, Texas 77030 USA.

${ }^{4}$ Corresponding author.

E-MAIL cozzlab@mendel.berkeley.edu; FAX (510) 643-1079.
}

Topo I, encoded by the topA gene, and topo III, encoded by the topB gene, are the type-1 enzymes (Sternglanz et al. 1981; Trucksis and Depew 1981; DiN ardo et al. 1982; Dean et al. 1983; Srivenugopal et al. 1984). Topo III is dispensable for cell viability, but may have important biological roles (DiGate and Marians 1988, 1989; Gangl off et al . 1994). topA del etions are tol erated only in the presence of compensatory mutations in other genes that influence the DNA supercoiling level (DiN ardo et al. 1982; Raji et al. 1985). Decatenation of intact duplex DN A rings can be carried out only by a type 2 topoisomerase. However, DN A replication produces catenated intermediates with gaps and nicks that could be unlinked by a type-1 topoisomerase. Topo III does this efficiently in vitro (Dean et al. 1983; Hiasa and M arians 1994).

We show that topo IV is, by far, the major decatenase of DNA replication products in E. coli and Salmonella typhimurium (Adams et al. 1992b; Khodursky et al. 1995; Zechiedrich and Cozzarelli 1995). Previous results from our laboratory, however, indicated that DN A gyrase, instead, was the principal decatenase of the products of site-specific recombination (Bliska and Cozzarelli 1987; Bliska et al. 1991; A dams et al. 1992a). To reconcile these results, several models have been suggested: 
The two topoisomerases might be compartmentalized within the cell; topo IV might be limited to action at the replication fork, whereas gyrase is free to unlink catenanes arising elsewhere; or the structures of the catenated products of replication and recombination may differ (Wang 1991; Adams et al. 1992b; de Boer 1993; Watt and Hickson 1994; Luttinger 1995; Ullsperger et al. 1995; Zechiedrich and Cozzarelli 1995).

The conclusion that gyrase was the principal decatenase was based chiefly on the observation that the quinol one norfloxacin blocked decatenation of the products of $\lambda$ integrase (Int) recombination in a wild-type strain, but not in a drug-resistant gyrase mutant (Bliska and Cozzarelli 1987). Resolvase-generated catenanes al so accumulated upon treatment of a wild-type strain with norfloxacin (Bliska et al. 1991; Adams et al. 1992a). At the time the recombination experiments were performed, however, topo IV had not yet been discovered. Furthermore, until recently, the only known target in bacteria of the quinol one antibiotics, such as norfloxacin and ciprofloxacin, was DNA gyrase (for review, see Drlica 1984). With the discovery and purification of topo IV, it was found that topo IV is also a target of the quinolones in vitro (Kato et al. 1992; Peng and Marians 1993). We showed that topo IV was a drug target in an $\mathrm{E}$. coli strain containing a quinolone-resistant mutant gyrase (Khodursky et al. 1995). Mutations in parC could impart drug resistance to topo IV in vitro and in vivo (Khodursky et al. 1995). These results have been confirmed (Chen et al. 1996; Heisig 1996; Kumagai et al. 1996; Yamagiahi et al. 1996) and other studies had already indi cated that topo IV can be a primary drug target in other bacteria (Belland et al. 1994; Ferrero et al. 1994). In addition, a clinical isolate of $\mathrm{E}$. coli that is hyperresistant to the quinolone anti biotics (Heisig and Wiedemann 1991) contains a mutation in topo IV that confers an extremely high level of drug resistance (Khodursky et al. 1995; Heisig 1996). Hence, topo IV is an important clinical target of quinolones. Therefore, we needed to test the role of topo IV in recombination.

We constructed an isogenic set of strains that enabled us to inhibit topo IV, gyrase, both enzymes, or neither enzyme rapidly and sel ectively with quinolones in vivo. These strains allowed us to address directly the roles of topo IV and gyrase in decatenation of the products of site-specific recombination by $\lambda$ Int or $\mathrm{Tn} 3$ resolvase. We show that topo IV decatenates the products of recombination just as it unlinks DN A replication intermediates. Our reinterpretation of the earl ier recombination experiments in wild-type strains is that the amount of norfloxacin used inhibited gyrase completely and topo IV only partially. The residual topo IV was insufficient to decatenate the recombination catenanes as they were no Ionger supercoiled because of DNA relaxation by topo I in the absence of gyrase activity. In the drug-resistant gyrase mutant, the partial activity of topo IV was sufficient to decatenate the negati vel y supercoiled catenanes. The role of gyrase in decatenation is to maintain negative supercoiling in the substrate DN A, which makes it a superior substrate for topo IV.
In the process of delineating the roles of the topoisomerases in recombination, we made the surprising discovery that topo IV has a strong DN A relaxation activity in vivo that, with gyrase and topo I, sets the cellular DNA supercoiling level. It was thought previously that only gyrase and topo I carried out this essential function (for review, see Wang, 1991).

\section{Results}

Effect of topo IV and gyrase on Int recombination in vivo

Our first series of experiments employed the Int recombination reaction. This site-specific recombinase reacts with $\rightarrow$ supercoiled plasmids containing directly re peated DN A-binding sites to form multiply linked catenanes (Spengler et al. 1985). In vivo, these catenanes are quickly unlinked by type-2 topoisomerases into free circles (Bliska and Cozzarelli 1987). The reaction protocol we used to determine which enzyme unlinks the Int products is schematized in Figure 1 . The strains were lysogens for a mutant phage $\lambda$, which contains the Int gene under control of the temperature-sensitive repressor, cl 857 (Bliska and Cozzarelli 1987). The strains harbored the Int recombination substrate pJB3.5d (Bliska and Cozzarelli 1987). Int expression was initiated by shifting the cul tures to $43^{\circ} \mathrm{C}$ for $10 \mathrm{~min}$ to inactivate the repressor. N orfloxacin was added (or not) and the cultures were shifted back to $30^{\circ} \mathrm{C}$ to activate the thermolabile wild-type Int protein (Guarneros and Echols 1973). Thus, recombination of the plasmid substrate and topoisomerase inhibition were initiated at the same time (time 0). Cultures were incubated at $30^{\circ} \mathrm{C}$ for up to 60 $\mathrm{min}$. If the topoisomerase responsible for decatenation is drug inhibited, then the recombined plasmid DNA would be trapped as catenanes.

Before we consider the fraction of products that is catenated, it is important to note that norfloxacin affects the frequency of recombination. The inhibition of topoisomerases not only blocks decatenation, but al so influences the level of cellular DNA supercoiling, which, in turn, modul ates recombination ( $N$ ash 1990). Because su-

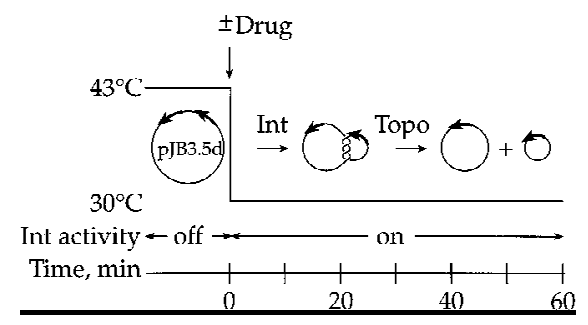

Figure 1. Experimental system for measuring the unlinking of catenanes produced by $\lambda$ Int recombination. Cells were grown at $30^{\circ} \mathrm{C}$ to a density of $70 \mathrm{Klett}$ units and shifted to $43^{\circ} \mathrm{C}$ where Int is expressed but is inactive. U pon downshift to $30^{\circ} \mathrm{C}$, Int recombines the substrate plasmid pJB3.5d to make multiply interlinked catenanes. A type-2 topoisomerase unlinks the catenanes to rel ease free 0.6 - and $2.9-\mathrm{kb}$ circles. 
percoiling affects transcription [indeed, even of the topoisomerases themsel ves (M enzel and Gellert 1983)], we limited transcription of Int to the time before the addition of norfloxacin to insure that the resultant changes in DNA supercoiling have no effect on Int synthesis, only on the ability of Int to recombine (Fig. 1).

We measured the effect of norfl oxacin on the extent of recombination in each of six test strains, LZ33-LZ38 (see Table 1). For convenience, we refer to these strains by the topo IV and gyrase genotypes. Plasmids were isolated at various times throughout the recombination reactions, nicked with DN ase I, and anal yzed by high resoIution gel electrophoresis and Southern blotting. The amount of label in the recombinant products as a percentage of the total label in all plasmid DNA for each strain is shown in Figure 2 . In this and two subsequent figures, the results are presented as bar graphs. The three panels on the left are gyrA ${ }^{+}$strains and the three on the right are strains with gyrA ${ }^{\mathrm{L} 83}$, which renders gyrase highly norfloxacin resistant. In the top row, parC is wild type; in the middle row, parC is resistant to norfloxacin to an intermediate degree (parC ${ }^{\mathrm{L80}}$ ); and in the bottom row, parC is highly resistant to norfloxacin (parC ${ }^{\mathrm{K} 84}$ ). For each strain, we show the amount of recombination in the presence of $0,30,60,90$, or $120 \mu \mathrm{m}$ norfloxacin. For each drug concentration, data are shown for $0,20,30,45$, and $60 \mathrm{~min}$ after drug addition and shift down to $30^{\circ} \mathrm{C}$. The drug concentrations were chosen based upon the $\mathrm{K}_{\mathrm{i}}$ values that we determined for the inhibition of topo IV or gyrase in vitro and in vivo (Table $2 \mathrm{~A}$; see Materials and Methods). From these $K_{i}$ values, we constructed Table 2B showing qualitatively the inhibition of wildtype or mutant gyrase and topo IV at the concentrations of drug used in this work.

In the absence of norfloxacin, the extent and rate of recombination were the same for each strain [Fig. 2, ( $\mathrm{N}$ or) $=0$ ], showing that the topoisomerase mutants have the same Int expression and activity as the wild-type strain. When gyrase was drug-resistant and thus able to maintain negative supercoiling, recombination occurred at all drug concentrations tested (Fig. 2, right panels). The drug resistance imparted by this gyrA allele exceeded $180 \mu \mathrm{m}$ norfloxacin (Table 2; data not shown).

In contrast, when gyrase was wild type, and thus inhibited by norfloxacin, recombination was clearly reduced by even the lowest drug concentration used, $30 \mu \mathrm{m}$ (Fig. 2, cf. left and right panels in each row). The surprising result was that the inhibition of recombination by norfloxacin was greatly affected by the drug resistance of topo IV (Fig. 2, left panels). When parC was wild type,

Table 1. Bacterial strains

\begin{tabular}{|c|c|c|}
\hline Strain & Genotype & Construction ${ }^{\mathrm{a}}$ or Reference \\
\hline CAG12183 & zei-3143::Tn10kan & Singer et al. (1989) \\
\hline C600 & F- thr-1 leu- 6 thi-1 lacY1 supE44 tonA21 & Kato et al. (1988) \\
\hline KL16 & Hfr thi & Yoshida et al. (1988) \\
\hline LZ1 & Hfr thi gyrA ${ }^{\text {L83 }}$ zei-723::Tn10 & Zechiedrich and Cozzarelli (1995) \\
\hline LZ2 & Hfr thi zei-723::Tn10 & Zechiedrich and Cozzarelli (1995) \\
\hline LZ21 & C600 except gyrA ${ }^{\mathrm{L} 83}$ zei-723::Tn10 parC ${ }^{\mathrm{L} 80}$, kan $^{\mathrm{R}}$ & Khodursky et al. (1995) \\
\hline LZ22 & C600 except zei- 723::Tn10 parC ${ }^{\mathrm{L} 80}, \mathrm{kan}^{\mathrm{R}}$ & Khodursky et al. (1995) \\
\hline LZ23 & C600 except gyrA ${ }^{\mathrm{L} 83}$ zei-723::Tn10 kan R & Khodursky et al. (1995) \\
\hline LZ24 & C600 except zei-723::Tn10 kan R & Khodursky et al. (1995) \\
\hline LZ27 & LZ21 except Tet ${ }^{\mathrm{S}}$ & fusaric acid $\mathrm{R}^{\mathrm{R}}$ \\
\hline LZ28 & LZ22 except Tet ${ }^{S}$ & fusaric acid ${ }^{R}$ \\
\hline LZ29 & LZ23 except Tet ${ }^{S}$ & fusaric acid ${ }^{\mathrm{R}}$ \\
\hline LZ30 & LZ24 except Tet ${ }^{S}$ & fusaric acid ${ }^{\mathrm{R}}$ \\
\hline LZ31 & W3101入 except gyrA ${ }^{\text {L83 }}$ zei-723::Tn10 & $\mathrm{P} 1(\mathrm{LZ1}) \times \mathrm{W} 3101 \lambda$, Tet $^{\mathrm{R}}$ \\
\hline LZ32 & W3101入 except zei-723::Tn10 & $\mathrm{P} 1(\mathrm{LZ2}) \times \mathrm{W} 3101 \lambda$, Tet $^{\mathrm{R}}$ \\
\hline LZ33 & LZ31 except parC ${ }^{\mathrm{L} 80}, \mathrm{kan}^{\mathrm{R}}$ & $\mathrm{P} 1(\mathrm{LZ22}) \times \mathrm{LZ31}, \mathrm{Kan}^{\mathrm{R}}$ \\
\hline LZ34 & LZ32 except parC ${ }^{\mathrm{L} 80}, \operatorname{kan}^{\mathrm{R}}$ & $\mathrm{P} 1(\mathrm{LZ22}) \times \mathrm{LZ32}, \mathrm{Kan}^{\mathrm{R}}$ \\
\hline LZ35 & LZ31 except kan ${ }^{R}$ & P1 $\left(\right.$ LZ24) $\times$ LZ31, $\operatorname{Kan}^{R}$ \\
\hline LZ36 & LZ32 except kan ${ }^{R}$ & $\mathrm{P} 1(\mathrm{LZ24}) \times \mathrm{LZ32}, \mathrm{Kan}^{\mathrm{R}}$ \\
\hline LZ37 & LZ31 except parC ${ }^{\mathrm{K} 84}, \mathrm{kan}^{\mathrm{R}}$ & P1(1644) $\times$ LZ31, Kan $^{R}$ \\
\hline LZ38 & LZ32 except parC ${ }^{\mathrm{K} 84}, \mathrm{kan}^{\mathrm{R}}$ & $\mathrm{P} 1(1644) \times \mathrm{LZ32}, \mathrm{Kan}^{\mathrm{R}}$ \\
\hline LZ49 & KL16 except zei-3143::Tn10kan & $\mathrm{P} 1(\mathrm{CAG} 12183) \times \mathrm{KL} 16, \mathrm{Kan}^{\mathrm{R}}$ \\
\hline LZ50 & N51 except zei-3143::Tn10kan & $\mathrm{P} 1(\mathrm{CAG} 12183) \times \mathrm{N} 51, \mathrm{Kan}^{\mathrm{R}}$ \\
\hline LZ53 & RS2入 except zei-3143::Tn10kan & $\mathrm{P} 1(\mathrm{LZ} 49) \times \mathrm{RS} 2 \lambda, \mathrm{Kan}^{\mathrm{R}}$ \\
\hline LZ54 & RS2 $\lambda$ except gyrA ${ }^{\text {L83 }}$ zei-3134::Tn10kan & $\mathrm{P} 1(\mathrm{LZ50}) \times \mathrm{RS} 2 \lambda, \mathrm{Kan}^{\mathrm{R}}$ \\
\hline N 51 & Hfr thi gyrA ${ }^{\mathrm{LB3}}$ & Yoshida et al. (1988) \\
\hline $\mathrm{RS} 2 \lambda$ & pyrF287 nirA trpR72 iclR7 gal25 rpsL195 top10 $\lambda$ (P80 xis1 cl 857) & Bliska and Cozzarelli (1987) \\
\hline W3101ג & $\mathrm{F}-\lambda(\mathrm{P} 80$ red114 xis-1 cl857) & Bliska and Cozzarelli (1987) \\
\hline 1643 & C600 except gyrA ${ }^{\mathrm{L} 83}$ zei-723::Tn10 parC ${ }^{\mathrm{K} 84}$, kan $^{\mathrm{R}}$ & Khodursky et al. (1995) \\
\hline 1644 & C600 except zei-723::Tn10 parC ${ }^{\mathrm{K} 84}, \mathrm{kan}^{\mathrm{R}}$ & Khodursky et al. (1995) \\
\hline
\end{tabular}

${ }^{a}$ Constructions are shown as chemical used for selection or as donor $\mathrm{x}$ recipient, selection. A bbreviations: (R) Resistant; (S) sensitive; (Tet) tetracycline; (Kan) kanamycin; (P1) source of transducing phage lysate. 


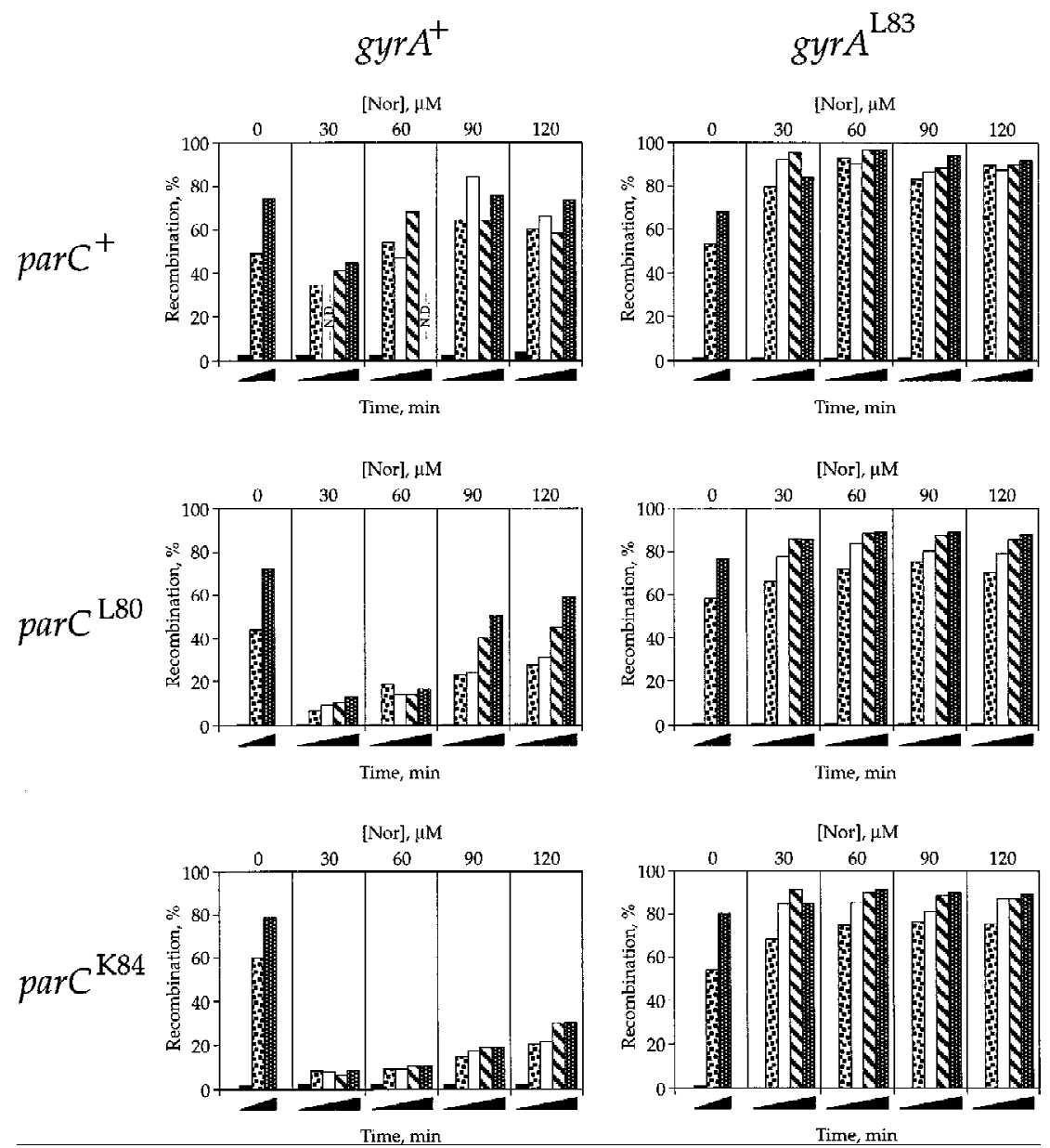

Figure 2. Effect of norfloxacin on Int recombination. The experiment was as described in the legend of Fig. 1. Plasmid DN A was isolated, subjected to el ectrophoresis on high resolution agarose gels, Southern blotted, and quantified by Phosphorlmager analysis. The total amount of plasmid DNA label was normalized to $100 \%$. The percentage of the total recombined plasmid is shown for various time points and drug concentrations [Nor] in each of the six strains. Time after shift down to $30^{\circ} \mathrm{C}$ is represented as black wedges. Samples were anal yzed at the following times after the addition of drug: 0 $\min (\boldsymbol{\square}), 20 \mathrm{~min}$ (squares in box), $30 \mathrm{~min}$ (white box), 45 (hatched box), and 60 min (dotted). The graphs are presented in a matrix array depending upon the states of the topo IV and gyrase alleles. $\left(\right.$ parC $^{+}$gyrA $\left.{ }^{+}\right)$LZ36; $\left(\right.$parC $^{+}$ gyrA ${ }^{\text {L83 }}$ ) LZ35; (parC ${ }^{\text {L80 }}$ gyrA ) LZ34; (parC ${ }^{\text {L80 }}$ gyrA ${ }^{\text {L83 }}$ LZ33; (parC ${ }^{\text {K84 }}$ gyrA ${ }^{+}$LZ38; (parC ${ }^{\text {K84 }}$ gyrA ${ }^{\text {L83 }}$ ) LZ37. (N.D.) N ot determined. Parts of these experiments were repeated three times. The exact values varied somewhat, but the rel ative values were al ways the same. For example, the $30 \mu \mathrm{m}$ drug, $20 \mathrm{~min}$ point for the double wild-type strain was done three times. The amount of recombination averaged $30 \% \pm 7 \%$ and the amount of catenation averaged $75 \%$ and varied $<4 \%$. The results here and in Figs. 3 and 5 are from one extensive experiment performed all on the same day. recombination was decreased, but still robust in the gyrA ${ }^{+}$strain, compared with the isogenic gyrA ${ }^{\text {L83 }}$ strain. Recombination was reduced with drug in the parC ${ }^{\text {L80 }}$ strain and even further reduced in the presence of the more resistant parC ${ }^{\mathrm{K} 84}$ allele.

The most direct explanation for these results is that topo IV lowers the $(\rightarrow$ supercoiling density of the substrate plasmids. The Int reaction studied here requi res $(\rightarrow$ supercoiled DNA (N ash 1990) and uninhibited topo IV relaxes the plasmid DNA and makes it an inferior substrate for Int. Accordingly, DN A relaxation by topo IV is almost completely blocked by norfloxacin in wild-type parC strains, partially blocked in the strain carrying the intermediate drug-resistant parC ${ }^{\mathrm{L} 80}$ allele, and is barely affected in the parC ${ }^{\mathrm{K} 84}$ strain when gyrase is wild type. The dependence of recombination on drug concentration is best explained by the inhibition of topo IV DNA relaxation activity at the highest norfloxacin doses. Thus, without the topoisomerases to al ter it, the DNA remains negatively supercoiled and highly recombinogenic.

Previously, the equilibrium balance of $(-)$ supercoiling has been thought to be controlled in a simple fashion by the opposing action of gyrase and topo I (Gellert 1981; Pruss and Drlica 1982; Wang 1985; Liu and Wang 1987). DNA gyrase pumps $(\rightarrow$ supercoils into DNA, whereas topo I sel ectively removes (-) supercoils. These functions are influenced by tracking processes such as transcription, which separates supercoiled DNA into $(+)$ and $(-)$ domains, and also depend upon DNA-anchoring sites that maintain these domains (Liu and Wang 1987; Cook et al. 1992; Lynch and Wang 1993). Previously, no role for topo IV in DNA supercoiling was observed (Wang 1991; A dams et al. 1992b; Khodursky et al. 1995; Zechiedrich and Cozzarelli 1995). However, topo IV is known to relax DN A in vitro (Kato et al. 1992) and in vivo when overexpressed (Free and Dorman 1994; McNairn et al. 1995).

\section{Effect of topo IV and gyrase on DNA supercoiling levels in vivo}

To test di rectly whether normal level s of topo IV have an effect on DN A supercoiling in vivo, we examined a portion of the DNA samples described in Figure 2 (before they were nicked) on agarose gels containing various concentrations of chloroquine. Chloroquine untwists circular DN A in a controlled manner and thereby allows the electrophoretic separation of DNA topoisomers and the measurement of supercoiling density $(\sigma)$ (Keller 1975). 
Table 2. Effects of norfloxacin on topo IV and DNA gyrase

A. $K_{i}$ values for gyrase and topo IV

\begin{tabular}{|c|c|c|c|c|}
\hline \multirow[b]{2}{*}{ Enzyme } & \multicolumn{2}{|c|}{ In vitro $K_{i}(\mu \mathrm{M})$} & \multicolumn{2}{|c|}{ In vivo $K_{i}(\mu M)$} \\
\hline & gyrase $^{a}$ & topo $\mathrm{IV}^{\mathrm{b}}$ & gyrase $^{a}$ & topo IV \\
\hline Wild type & 0.9 & 7.6 & 6 & 15 \\
\hline ParC L80 & - & 88 & - & $>90$ \\
\hline ParC 84 & - & 245 & - & $>120$ \\
\hline GyrA ${ }^{\text {L83 }}$ & 34.5 & - & 180 & - \\
\hline
\end{tabular}

B. Inhibition of gyrase and topo IV ${ }^{\mathrm{C}}$

\begin{tabular}{|c|c|c|c|c|c|c|c|c|c|}
\hline \multicolumn{2}{|c|}{ Strain } & \multicolumn{2}{|c|}{$30 \mu \mathrm{M}$} & \multicolumn{2}{|c|}{$60 \mu \mathrm{M}$} & \multicolumn{2}{|c|}{$90 \mu \mathrm{M}$} & \multicolumn{2}{|c|}{$120 \mu \mathrm{M}$} \\
\hline gyrA & parC & gyrase & topo IV & gyrase & topo IV & gyrase & topo IV & gyrase & topo IV \\
\hline wt & wt & - & $H-$ & - & - & - & - & - & - \\
\hline wt & L80 & - & + & - & + & - & $H-$ & - & $H-$ \\
\hline wt & K84 & - & + & - & + & - & + & - & + \\
\hline L83 & wt & + & $H-$ & + & + & + & - & + & - \\
\hline L83 & L80 & + & + & + & + & + & $H-$ & + & $H-$ \\
\hline L83 & $\mathrm{K} 80$ & + & + & + & + & + & + & + & + \\
\hline
\end{tabular}

aM easure by DNA supercoiling

bM easured by decatenation

'The concentration of norfloxacin is shown;,-+- , and + correspond to complete, partial, and no inhibition, respectively, of the enzyme in the strain composed of the gyrA and parC alleles indicated in the first two columns. (wt) Wild type.

Gels were blotted and the results were analyzed with a Phosphorlmager.

The results are presented as a histogram similar to Figure 2 except the ordinate shows $\sigma$ (Fig. 3). Completely relaxed DN A has a $\sigma$ value of 0 . In the absence of drug, the $\sigma$ for plasmid pJB3.5d in all strains was -0.075 (leftmost set in each panel). This shows that the topoisomerases in the mutant strains are functioning equally in the absence of drug. When gyrA was drug-resistant, norfloxacin had little effect on $\sigma$ (Fig. 3, right panels). When gyrase was wild type, however, the supercoiling level was reduced to a degree dependent upon the parC allele (Fig. 3, left panels). The more drug-resistant the parC allele was, the greater the observed DNA relaxation. Therefore, the decrease in recombination seen in Figure 2 is caused by the simultaneous inhibition of $(\rightarrow$ supercoiling by DNA gyrase and the rapid DNA relaxation by drug-resistant topo IV (and topo I). Further, in the wildtype strain, topo IV is inhibited by norfloxacin and only topo I relaxes the plasmid DNA (Fig. 2, top left). Topo I alone, then, must not be able to relax DNA beyond $\sigma \sim-0.05$ in vivo. Topo IV, on the other hand, can relax the DNA to near completion $(\sigma \sim-0.012)$ in the drugresistant parC strains.

To ill ustrate the effect of (-) supercoiling on Int recombination, we plotted the percentage of recombination as a function of $\sigma$ for all the data in Figures 2 and 3 (Fig. 4). The transition from a baseline level of recombination to maximal recombination is surprisingly sharp and the midpoint lies around $a$ of -0.05 . This supercoiling level required for recombination is near measured wild-type $\sigma$ levels for various plasmids and the chromosome (Sinden et al. 1980; for review, see Wang 1984). Clearly, $\lambda$ Int requires highly $(-)$ supercoiled DNA in vivo and this DNA is modulated by topo IV relaxation.

Topo IV decatenates products of Int recombination in vivo

Even when $\sigma$ was lowest (when gyrase was inhibited and topo IV was not), recombination could be detected. Thus, decatenation of the recombination products could be measured. The high-resolution gels used for Figure 2 allow separation of the catenanes from both unreacted Int substrate plasmids and unlinked products. From these data, we measured the amount of recombination (catenanes plus free circles) for each time point and normalized it to $100 \%$. Of that, the amount of recombined plasmid DNA that was catenated was plotted for each strain (Fig. 5). The histogram panels are as in Figures 2 and 3. In the absence of drug, no appreciable amount of catenanes was seen at any time point. Nearly all of the plasmids that were recombined in the parC ${ }^{+}$gyrA ${ }^{+}$strain re mained as catenanes when norfl oxacin was present, even 60 min after recombination was initiated (Fig. 5, upper left). At the other extreme, the double drug-resistant mutants, parC ${ }^{\mathrm{L} 80}$ gyrA ${ }^{\mathrm{L} 83}$ or parC ${ }^{\mathrm{K} 84}$ gyrA ${ }^{\mathrm{L} 83}$, showed very few catenanes with drug, about $10 \%$ (middle and lower right panels). These data establish that topo IV and gyrase are the only relevant decatenases of the products of Int recombination in $\mathrm{E}$. coli.

If gyrase were solely responsible for decatenation (as previously thought), then a gyrA ${ }^{+}$strain with drug-resistant topo IV should have the same level of catenation as the parC ${ }^{+}$gyrA ${ }^{+}$strain. Instead, the strains with drug resistant topo IV, parC $^{\mathrm{L} 80}$ gyrA $^{+}$(Fig. 5, middle left) and 

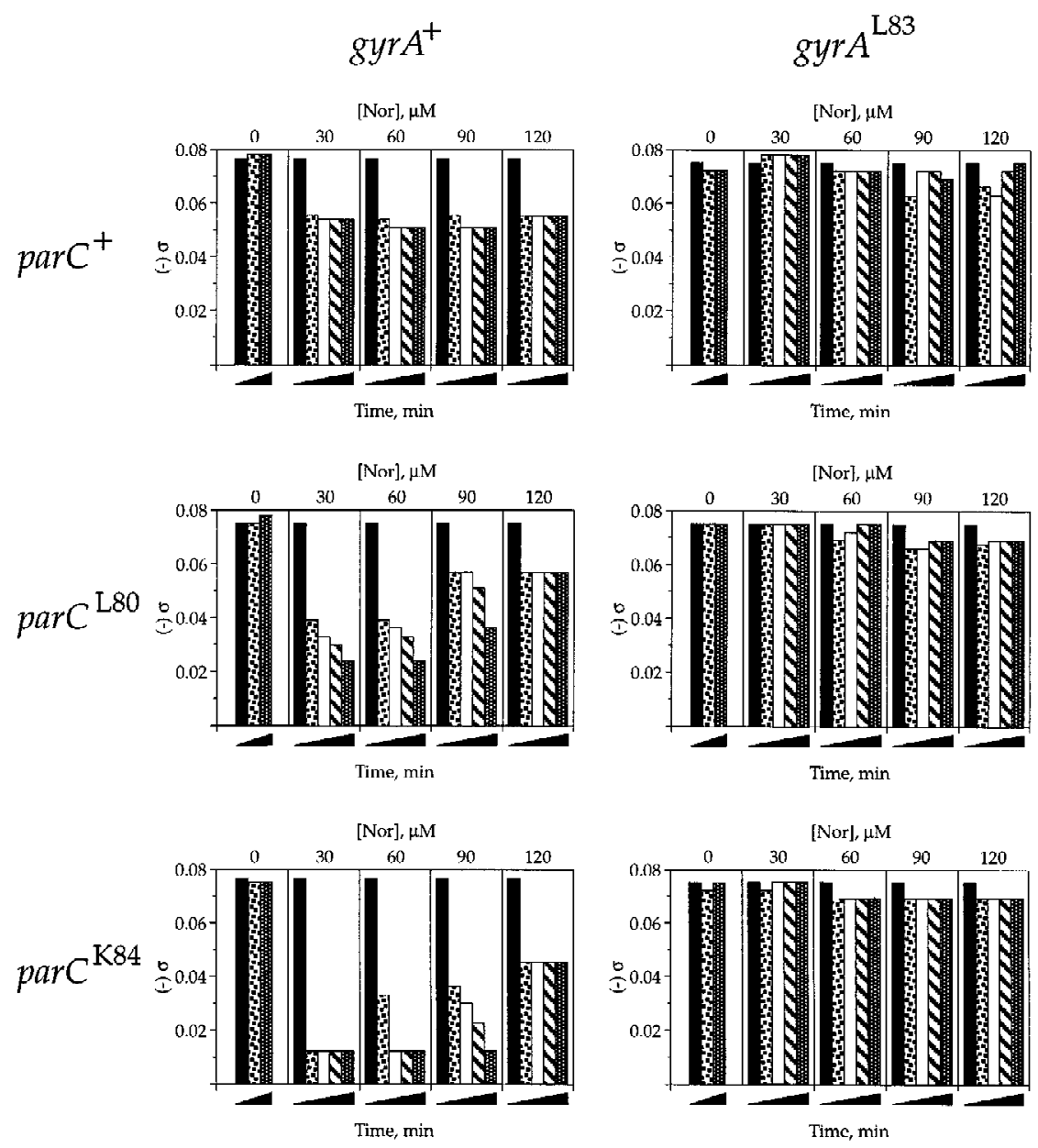

Figure 3. Effect of norfloxacin on plasmid DNA supercoiling levels. Supercoiled plasmid DNA from the experiment described in Fig. 2 was separated and visualized on agarose gels containing 0,2 , 4 , or $8 \mu \mathrm{g} / \mathrm{ml}$ chloroquine and compared with plasmids of known $\sigma$. Shown are the $\sigma$ values as quantified by the band counting method (Keller 1975). A $\sigma$ of zero was taken as the midpoint of the topoisomer distribution after plasmid DNA relaxation in vitro with calf thymus topo I. The time points and symbols are the same as in Fig. 2.

$\operatorname{parC}^{\mathrm{K} 84} \mathrm{gyrA}^{+}$(bottom left) have substantial ly lower levels of catenanes than the strain with drug-resistant gyrase (parC ${ }^{+}$gyrA $^{\mathrm{L} 83}$ ). At higher drug concentrations, first the parC ${ }^{\mathrm{L} 80}$ and then the parC ${ }^{\mathrm{K} 84}$ drug-resistance is partially overcome, as indicated by the increase in cat-

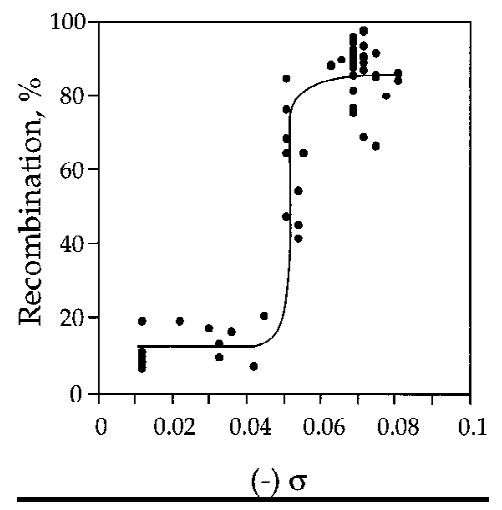

Figure 4. Effect of DNA supercoiling $(\sigma)$ on Int recombination. The amount of recombination as a function of $\sigma$ was assessed by plotting all the data from Figs. 2 and 3. The line is drawn for ease of visualization. enanes at $90 \mu \mathrm{m}$ and $120 \mu \mathrm{m}$ norfloxacin, respectively. These results are expected if topo IV, not gyrase, is the primary decatenase of recombination products.

Gyrase plays some role in decatenation of recombination products because there is roughly a $30 \%$ difference in the levels of catenation between the parC ${ }^{+}$gyrA ${ }^{+}$and parC ${ }^{+}$gyrA ${ }^{\text {L83 }}$ strains (Fig. 5, cf. top left and right panels). Gyrase may directly decatenate this fraction of catenanes. Alternatively, because topo IV unlinks supercoiled catenanes four-fold better than it unlinks relaxed catenanes in vitro (Ullsperger and Cozzarelli 1996), it is possible that the role played by gyrase is to boost the decatenation activity of residual uninhibited topo IV by supercoiling the plasmids. As a result, when supercoiling is normal (in gyrA ${ }^{\text {L83 }}$ strains), residual topo IV decatenates more efficiently than it does when the DNA is relaxed.

To visual ize better the relationship between supercoiling $(\sigma)$ and decatenation, we plotted this dependence for every data point from Figure 5 for parC ${ }^{+}$strai ns, in which catenanes are preserved by drug addition. As with recombination (Fig. 4), $\sigma$ affects strikingly the amount of decatenation (Fig. 6). There is an abrupt decrease in the fraction of catenanes over the relatively small supercoiling density range $(-0.05$ to -0.075$)$. 
Figure 5. Effect of norfloxacin on decatenation of Int recombination products. The amount of recombined DN A from Fig. 2 was further broken down into catenanes and free circles (decatenated). The percentage of the total recombined plasmid that was catenated is shown.

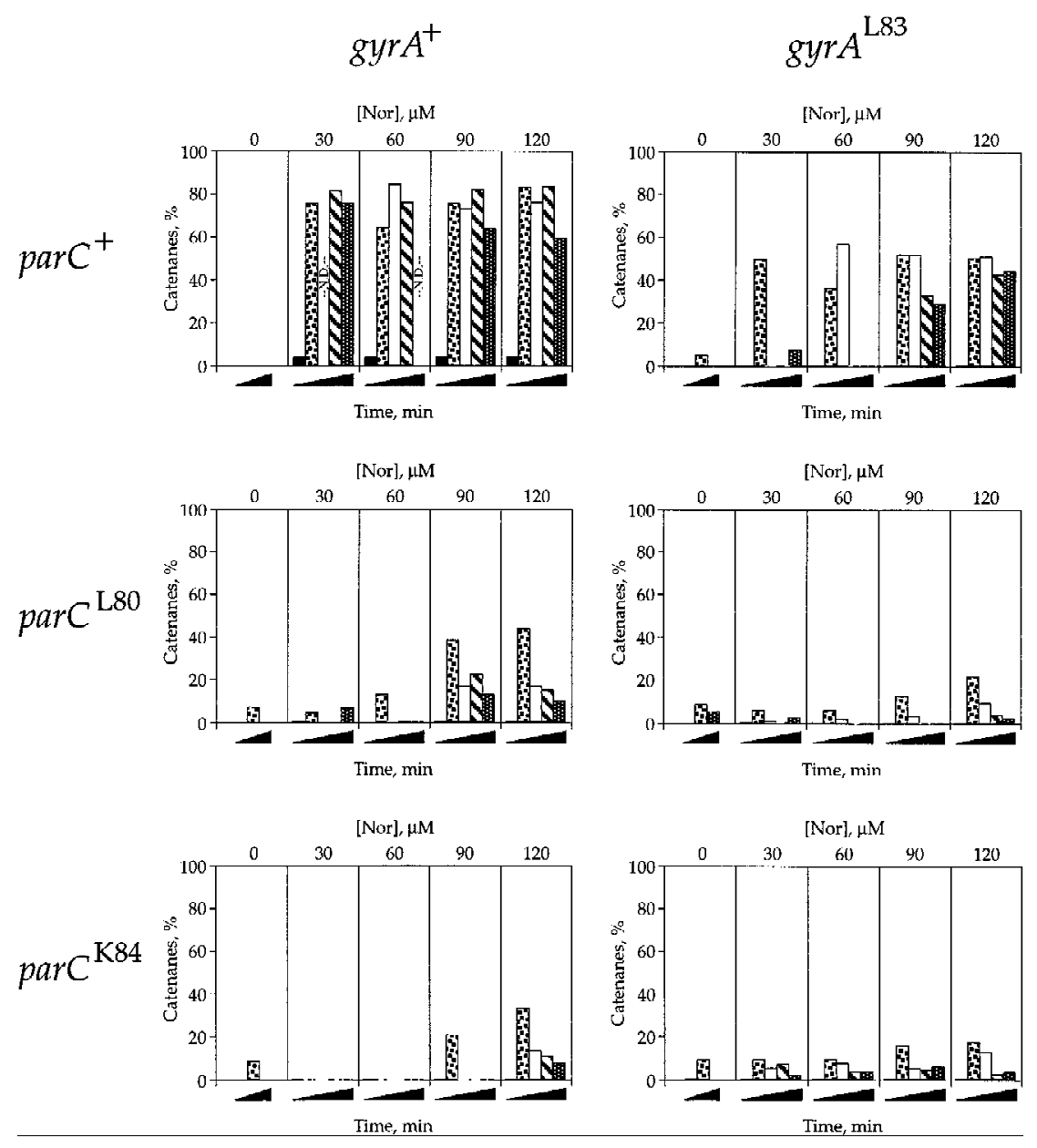

We carried out the following experiment to test whether the role of DNA gyrase is to introduce negative supercoils into the DNA, which is then decatenated by topo IV exclusively. We reasoned that if this hypothesis is correct, then if we could block DNA relaxation, the inhibition of gyrase would not result in a loss of super-

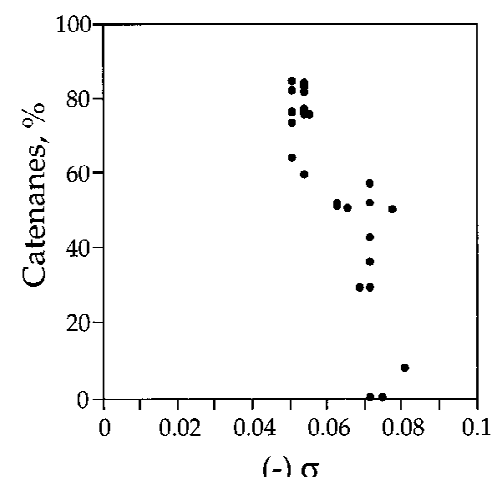

Figure 6. Effect of DNA supercoiling $(\sigma)$ on decatenation. The correlation between decatenation and $\sigma$ is shown for every parC ${ }^{+}$data point in Fig. 5. coiling. The consequence would be that recombination, supercoiling, and catenation should now be the same in the gyrA ${ }^{+}$and gyrA ${ }^{\mathrm{L} 83}$ strains after the treatment with norfloxacin. Although we knew from the data in Figures 2 and 3 that topo IV was able to relax DN A in the presence of topo I, we expected the role of topo I to predominate because it has been considered to be the primary $(\rightarrow$ supercoil relaxation enzyme in the cell (for review, see Wang 1991). We moved our drug-resistant and wild-type parC and gyrA alleles into a strain RS2 $\lambda$, which contains a mutation in topo I, top10, which reduces topo I activity 100-fold (DiN ardo et al. 1982).

The experiment proved to be more complex than we had antici pated, but for an interesting reason. After inhibition of gyrase by drug, topo IV al one was able to relax the DN A to near completion in the topo I mutant (data not shown). Although this result confounded our original intent, we obtai ned useful information. In these experiments, topo IV was wild-type and topo I was mutant. In the presence of drug, there was a fourfold faster initial rate of recombination in the gyrA ${ }^{\mathrm{L83}}$ strain than in the gyrA ${ }^{+}$control (Fig. 7A). In addition, recombination reached $95 \%$ in the strain with drug-resistant gyrase, but never exceeded $50 \%$ in the wild-type strain. Even without topo I activity to relax the DNA, the level of DNA 
supercoiling was dependent upon gyrase activity. The value of $\sigma$ after the addition of drug was -0.053 in the strain with wild-type gyrase, but reached the very high level of -0.093 in the gyrA ${ }^{\mathrm{L} 83}$ strain. Therefore, through its effect on $\sigma$, gyrase has an effect on recombination.

Our chief interest is in the portion of recombined DNA that was catenated (Fig. 7B). The majority (70\%$90 \%$ ) of the DNA remained catenated after drug treatment, but as in Figure 5, there was $\sim 20 \%$ difference in catenation depending on whether gyrase was drug resistant. This difference is small compared with the differences in recombination and $\sigma$, however. With time, the catenanes are unlinked slightly in both strains. As revealed from the slopes of the least squares fit lines of the kinetic data, the unlinking activity when gyrase is drug resistant is $\sim 3$.5-fold greater than the unlinking activity when gyrase is wild type. For comparison, we show the rate of catenane turnover when topo IV is active and gyrase is not in a parC ${ }^{\mathrm{K} 84} \mathrm{gyrA}^{+}$strain. This rate is $\sim 25-$

A

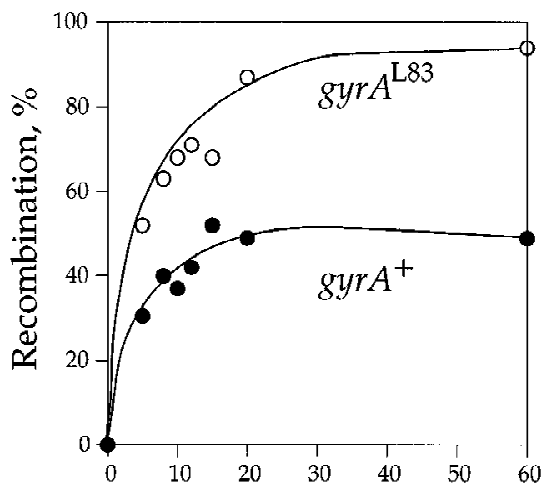

B

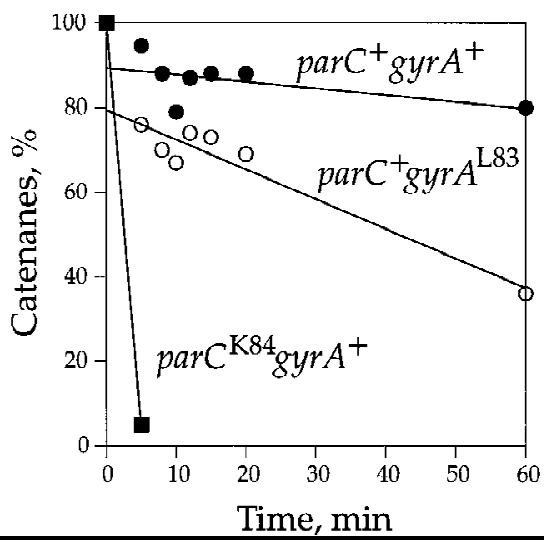

Figure 7. Kinetics of recombination and decatenation. (A) Rate of recombination in top10 parC ${ }^{+}$gyrA $^{+}(\mathrm{LZ53}$; $)$ and top10 parC $^{+}$gyrA ${ }^{\text {L83 }}$ (LZ54; O) strains. The experiment was as outlined in Figs. 1 and 2. The drug concentration was $90 \mu \mathrm{m}$. (B) A mount of catenation in topl0 parC $^{+} \mathrm{gyrA}^{+}(\mathbf{O})$ and top10 parC $^{+}$ gyrA $^{\mathrm{L} 83}(\bigcirc)$ strains. Catenane turnover in a parC ${ }^{\mathrm{K} 84} \mathrm{gyrA}^{\mathrm{L} 83}$ strain $(\mathrm{LZ37}$; ) is shown for comparison. From the relative slopes, catenane unlinking when gyrase is active and topo IV is inhibited $(O)$ is 3.5-fold faster than when both enzymes are inhibited ( $)$ and 25-fold faster than when topo IV is uninhibited (ם).

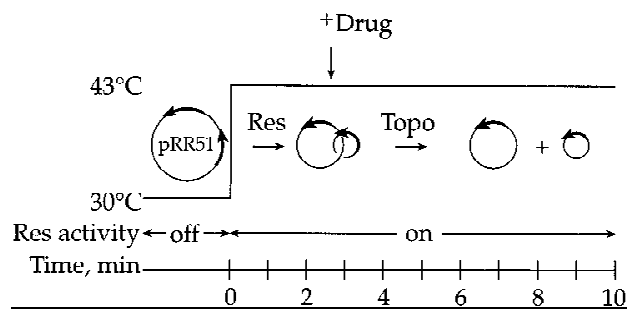

Figure 8. Experimental system for measuring decatenation of the products of resolvase recombination. The cells were grown at $30^{\circ} \mathrm{C}$ and then shifted to $43^{\circ} \mathrm{C}$ to induce resolvase expression. The enzyme recombines the two directly repeated sites on the substrate plasmid DN A and the product is a singly linked (twonoded) catenane. The sizes of the rings were 2.75 and $3.2 \mathrm{~kb}$. A type-2 topoisomerase unlinks the catenanes to generate free circles. Drug (norfloxacin) was added after recombination but before most unlinking.

fold faster than when gyrase alone is active. Therefore, the gyrase contribution to the rate of decatenation is far less than that of topo IV. Overall, these results are the same as those for the wild-type topo I strains and indicate that there are two rates of decatenation-an efficient unlinking by uninhibited topo IV and a rate $\sim 25-$ fold slower, which we believe is carried out by incompletely inhibited topo IV. Residual topo IV is boosted by the high level of negative supercoiling in the gyrA ${ }^{\text {L83 }}$ strain.

Topo IV decatenates the products of resolvase recombination in vivo

The most common plasmid catenane type in E. coli is the singly linked catenane (Wasserman and Cozzarelli 1986). A singly linked (two-noded) catenane can arise from DN A replication, type-2 topoisomerization, or recombination (Wasserman et al. 1988). The two-noded catenane is structural ly unique among catenanes in that there is no strain in the DNA introduced by the link (Wasserman and Cozzarelli 1986). Therefore, there is not the same enthal pic drive to decatenation as with multiply interl inked catenanes. Because of this and because of the complexity of the results with Int, an independent evaluation of the roles of topoisomerases in unlinking recombination catenanes was desirable. Therefore, we tested whether topo IV also played the key role in the unlinking of the two-noded catenanes formed by Tn3 resolvase.

As with Int, resolvase expression was under the $\lambda$ phage $p_{L}$ promoter controlled by the temperature-sensitive cl 857 repressor (Bliska et al. 1991). There were two differences between the Int and resolvase systems (Fig. 8). First, because resolvase is active at $43^{\circ} \mathrm{C}$, the entire experiment was conducted at $43^{\circ} \mathrm{C}$ and some recombination takes place before the addition of the topoisomerase inhi bitor (140 sec later). Second, the resolvase gene was in a multicopy plasmid instead of a single $\lambda$ chromosomal insertion and was, therefore, expressed at a 
much higher level (Bliska 1990). Because of the high expression levels and the recombination before topoisomerase inactivation, the time scale was much faster for resolvase than for Int. The substrate used, pRR51, contains directly repeated resolvase-binding sites and is recombined into two-noded catenanes, which are unlinked by topoisomerases in vivo (Bliska et al. 1991).

We focused on the gyrA ${ }^{\text {L83 }}$ strains because in gyrA ${ }^{+}$ strains there was minimal recombination as the plasmid substrate was rel axed at even the lowest drug levels examined and resolvase absolutel y requi res $(-)$ supercoiling (Reed 1981; Krasnow and Cozzarelli 1983; Bliska et al. 1991; Benjamin et al. 1996). In the gyrA ${ }^{\text {L83 }}$ strains, the plasmid DN A remained fully $(\rightarrow$ supercoiled in up to 200 $\mu \mathrm{m}$ norfloxacin (data not shown). In the absence of drug, the rate of resolvase recombination and subsequent decatenation was identical in all strains (data not shown). With increasing concentrations of norfloxacin, increasing amounts of recombination products were trapped as catenanes when topo IV alone was inhibited (parC ${ }^{+}$

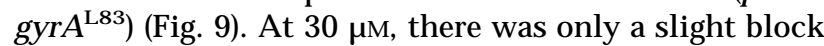
of decatenation. At $60 \mu \mathrm{m}$, half of the recombined plasmid was catenated. In contrast, when topo IV and gyrase were both resistant to drug (parC ${ }^{\mathrm{L80}} \mathrm{gyrA}^{\mathrm{L83}}$ ), there was a rapid unlinking of the catenanes into free circles even with norfloxacin as high as $300 \mu \mathrm{m}$. Although we could make no reliable quantitation, we observed catenanes in the parC $^{+}$gyrA $^{+}$strain and not in the parC ${ }^{\mathrm{L80}} \mathrm{gyrA}^{+}$ strain (data not shown). We conclude that topo IV is al so the primary decatenase of singly linked recombination products.

\section{Discussion}

By use of isogenic strains with various combinations of alleles encoding wild-type and drug-resistant gyrase and topo IV, we have determined the division of labor of the type-2 topoisomerases in the cell. We find that topo IV, not gyrase, is the enzyme that unlinks the catenated in-

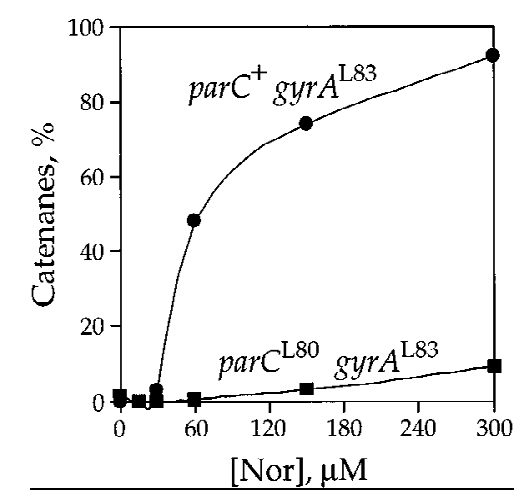

Figure 9. Effect of topo IV on decatenation of resolvase recombination products. The fraction of plasmid DNA that was catenated after $10 \mathrm{~min}$ at $43^{\circ} \mathrm{C}$ is shown as a function of norfloxacin ( $\mathrm{N}$ or) concentration. Two strains were assayed: $\operatorname{parC}^{+} \mathrm{gy}$ rA $^{\mathrm{L83}}$ (LZ29; $)$ ) and parC ${ }^{\mathrm{L} 80}$ gyrA ${ }^{\mathrm{L} 83}$ (LZ27; $\left.\mathbf{\square}\right)$. termediates of two different recombinases. Our conclusion that topo IV is the primary decatenase of recombination intermediates differs from the earlier conclusion that DN A gyrase was responsible (Bliska and Cozzarelli 1987; Bliska et al. 1991). Our data agree with the earlier results, but because they are far more extensive, lead to the revised interpretation. These results, combined with our previous work with DNA replication intermediates (Zechiedrich and Cozzarelli 1995), allow us to conclude that topo IV is the primary enzyme for all decatenation in the cell.

\section{The role of gyrase in decatenation}

Although topo IV is the major unlinking enzyme, gyrase does have an effect on decatenation. This is apparent from the reduction in decatenation after inhibition of gyrase with drug (Figs. 5 and 7). There are two ways that gyrase could promote decatenation. First, gyrase might directly unlink catenanes, but at a rate 25 -fold lower than that of topo IV (see Fig. 7). This contribution is similar to what we previously estimated for DN A gyrase decatenation of replication intermediates, which was roughly 100 -fold less than the contribution of topo IV (Zechiedrich and Cozzarelli 1995). The weak activity of gyrase was not sufficient to prevent catenation of replicated plasmids and a partition defect phenotype of conditionally lethal topo IV mutants (Kato et al. 1988; Schmid 1990).

The second possibility is that gyrase negatively supercoils the catenanes, which makes them superior substrates for topo IV decatenation. There are three arguments in favor of this possibility. (1) Purified topo IV unlinks supercoiled catenanes at least fourfold faster than relaxed catenanes in vitro (Ull sperger and Cozzarelli 1996) and at equilibrium supercoiling favors plasmid decatenation by more than two orders of magnitude (Rybenkov et al. 1997). The reduction in decatenation after norfloxacin addition to the gyrA ${ }^{+}$strain compared with the resistant mutant in all experiments correlated with $\sigma$ value; $(\rightarrow$ supercoiling promotes decatenation (Fig. 6). (2) If drug-resistant gyrase were directly decatenating some fraction of the catenanes, then the inhibition of topo IV should not alter that fraction. Instead, decatenation is far better when topo IV is drug resistant (Fig. 5). If anything, the presence of a drug-resistant topo IV should impair any direct decatenation by gyrase be cause topo IV relaxes the plasmid DNA and gyrase was also found to unlink supercoiled substrates better than relaxed substrates in vitro (Ullsperger and Cozzarelli 1996). (3) The turnover of the catenanes is blocked in the parC $^{+}$gyrA ${ }^{\text {L83 }}$ strain at the highest drug concentrations used (Fig. 5) even though gyrase is still fully functional [as evidenced by the complete recombination (Fig. 2) and unaltered supercoiling (Fig. 3) at the same drug concentrations]. Uninhibited gyrase should be able to continue to decatenate if it is responsible directly for decatenation.

If supercoiling by gyrase is inhibited, the activity of the drug-resistant topo IV on the relaxed DNA is still 
sufficient to completely unlink the catenanes. This is shown by the complete decatenation in the parC $\mathrm{C}^{\mathrm{K} 84}$ gyrA ${ }^{+}$strain in $90 \mu \mathrm{m}$ or less norfloxacin. Topo IV is only barely able to keep up with decatenation, however, because even the partial inhibition of topo IV in the parC ${ }^{\mathrm{L} 80} \mathrm{gyrA}^{+}$strain causes an increase in the proportion of catenanes.

We conclude that the role of gyrase in decatenation is to introduce negative supercoils into plasmid DNA, which makes a superior substrate for topo IV.

\section{The role of topo IV in DNA supercoiling}

It has been long thought that only two topoisomerases, topo I and DN A gyrase, counteracted each other to maintain the level of DNA supercoiling in bacteria (for review, see Wang 1991). Topo I removes (-) supercoils and DNA gyrase introduces $(\rightarrow$ supercoils. Here, we show that topo IV has a potent relaxing activity in vivo that al most completely removes $(\rightarrow$ supercoils after the inhibition of gyrase (Fig. 3). The extent of DNA relaxation by topo IV ( $\sigma=-0.012$; Fig. 3 , bottom left) exceeds the extent of relaxation by topo I ( $\sigma=-0.055$; Fig. 3, top left). The relaxation activity of topo IV was missed before because the drugs used to inhibit gyrase al so inhibited topo IV, the same reason that the role of topo IV in decatenation of recombination intermediates was missed. Only when we used a drug-resistant topo IV were the new activities reveal ed. These results call for a reexamination of previous research on DN A supercoiling in bacteria and we have addressed the rel ative importance of the topoi somerases in DN A supercoiling in a separate study (E.L. Zechiedrich, A.B. Khodursky, and N.R. Cozzarelli, in prep.).

Our findings reveal a complete division of labor between topo IV and DN A gyrase. Through the same DN A strand-passage mechanism, these homologous topoisomerases perform radically different functions in the cell. Topo IV decatenates replication and recombination intermediates as well as relaxes DNA supercoils. DNA gyrase introduces (-) supercoils in DN A. We speculate that, when examined more closely, perhaps other enzymes that are considered to be redundant may also have distinct roles in vivo.

\section{Materials and methods}

Chemicals and reagents

$\left[\alpha^{-32} \mathrm{P}\right] \mathrm{dCTP}(250 \mathrm{mCi} / \mathrm{mmole} ; 1 \mathrm{Ci} / \mathrm{ml})$ was from $\mathrm{NEN}$. The supercoiled DNA and 1 kilobase ladders were from GIBCO BRL. Proteinase $K$ was from Boehringer-Mannheim. Norfloxacin, fusaric acid, chlorotetracycline, chloroquine, RN aseA, and DNAse I were from Sigma. Multiprime DNA-labeling kit was from Amersham and Nytran (MSI) transfer membrane from Fisher.

\section{Bacterial strains and plasmids}

The bacterial strains used in this study are listed in Table 1. Four isogenic sets of strains containing all possible combina- tions of drug-resistant and wild-type alleles of gyrA and parC were constructed. Two sets were based upon the parental strain C600 that we used in earlier work (Khodursky et al. 1995; Zechiedrich and Cozzarelli 1995). The set of strains used to measure $K_{i}$ values in vivo were LZ21-24, 1643, and 1644. For the resolvase experiments, the set was LZ27-30. The strains used for the Int experiments were derived from the parental lysogen strain W3101ג (Bliska and Cozzarelli 1987; Adams et al. 1992a) and were designated LZ33-38. The topo I mutant strains were LZ53 and LZ54. In the text, for simplicity, we refer to these strains mostly by their parC and gyrA allelic states. The Int substrate plasmid was pJB3.5d (Bliska and Cozzarelli 1987). The resolvase expression vector, pJBREScl (Bliska et al. 1991), and the resolvase substrate, pRR51 (Reed 1981), have been described previously.

\section{Strain construction}

The construction of the tet-linked gyrA ${ }^{+}$and gyrA ${ }^{\text {L83 }}$ (Zechiedrich and Cozzarelli 1995) and kan-linked parC ${ }^{+}, \operatorname{parC}^{\mathrm{L} 80}$, and parC $^{\mathrm{K} 84}$ (Khodursky et al. 1995) strains were described previously. Because the resolvase substrate plasmid pRR51 conferred tetracycline resistance, we used the method of Bochner et al. (1980) to isolate tet ${ }^{\mathrm{s}}$ versions of these strains except that the final concentration of fusaric acid was increased to $24 \mu \mathrm{g} / \mathrm{ml}$ and chlorotetracycline to $100 \mu \mathrm{g} / \mathrm{ml}$. For the Int experiments, the tet-linked gyrA or kan-linked parC alleles were transduced with $P 1_{\text {vira }}$ (Miller 1972) into W3101入. The strains containing mutant topo I were made by transferring the kan marker from CAG12183 into strains N51 and KL16 (Yoshida et al. 1988; Singer et al. 1989). Then the gyrA ${ }^{\mathrm{L83}}$ or gyrA ${ }^{+}$gene with its linked kan marker was transduced into the lysogen RS2 $\lambda$ (Bliska and Cozzarelli 1987). The presence of the lysogen was verified by temperature sensitivity at $42^{\circ} \mathrm{C}$. The presence of the topo I mutation was verified by the increased plasmid supercoiling.

\section{Experimental rationale}

To repeat the earlier experiments as closely as possible, we used the same recombi nase expression systems and substrates for Int and resolvase (Bliska and Cozzarelli 1987; Bliska et al. 1991; Adams et al. 1992a). We looked at two different recombinases not only to test the generality of our results, but also to assay the decatenation of two different types of catenanes-singly linked and multiply linked. Because the sensitivity of DNA gyrase and topo IV to norfloxacin in vivo varies only by about twofold (Table 2; Khodursky et al. 1995), we had to use drugresistant forms of the enzymes to distinguish them from each other. These drug-resistant enzymes have $K_{i}$ values one to two orders of magnitude greater than their wild-type counterparts (Table 2A). By use of drug-resistant and wild-type alleles, we could inhibit one enzyme without affecting the other (T able 2B).

\section{Inhibition of topo IV and gyrase with norfloxacin}

To determine the drug sensitivity of the catalytic activity of the enzymes in vivo, we measured the amount of drug required to inhibit by $50 \%$ the supercoiling activity of gyrase and the decatenation activity of topo IV. Of course, quinolone antibiotics are not merely inhibitors of the topoisomerases. They act by the so-called poisoning mechanism whereby the cleaved DNA intermediate in the topoisomerase reaction is stabilized (Kreuzer and Cozzarelli 1979; Tewey et al. 1984). We do not include such covalent enzyme-DNA complexes in our analyses. However, they represent $\measuredangle \%$ of the plasmids (data not shown). Therefore, the change in plasmid topology levels that we analyze result 
from the removal of the topoisomerase being tested. Steadystate supercoiling of plasmid pBR322 DN A was chosen to be the measure of gyrase activity. The $K_{i}$ value for gyrase was defined as the minimal concentration of antibiotic that caused a twofold decrease in the amount of the topoisomer closest to the mean value.

Accumulation of DNA replication catenanes was used to determine the extent of topo IV inhibition by norfloxacin. The $K_{i}$ value for topo IV was defined as the minimal drug concentration at which half of the newly replicated DNA was catenated after a 0.5-min pulse (see Khodursky et al. 1995; Zechiedrich and Cozzarelli 1995). M easurement of the inhibition of topo IV was possible only in the presence of the drug-resistant gyrA because with wild-type gyrase, DNA replication was inhibited at drug concentrations much lower than those that inhibited topo IV (Khodursky et al. 1995). The $K_{i}$ values in vitro and in vivo are summarized in Table 2A. We were unable to determine the amount of drug needed to overcome the resistance of parC ${ }^{\mathrm{K} 84}$ in vivo because the resistance of the gyrA ${ }^{\text {L83 }}$ allele was overcome first. For the same reason, we could only estimate the $K_{i}$ value for parC ${ }^{\mathrm{L} 80}$. We used the $\mathrm{K}_{\mathrm{i}}$ values in vitro and in vivo (Table $2 \mathrm{~A}$ ) to assess the range of drug concentrations that would be active against the mutant enzymes in our experiments (Table 2B). For $30 \mu \mathrm{m}$ or higher norfloxacin, wild-type gyrase was inhibited. The $(\rightarrow$ supercoiling activity of drug-resistant gyrase in vivo was not inhibited until $>180 \mu \mathrm{m}$ norfloxacin. ParC ${ }^{+}$was mostly inhibited at $30 \mu \mathrm{M}$ and completely blocked at higher concentrations. ParC ${ }^{\mathrm{L} 80}$ was unaffected at $60 \mu \mathrm{M}$ and was inhibited at $90 \mu \mathrm{m}$ or higher. ParC ${ }^{\mathrm{K} 84}$ was slightly inhibited at 120 $\mu \mathrm{M}$, but was not at the lower drug concentrations.

\section{Int recombination}

The assay used for Int recombination (Bliska and Cozzarelli 1987; Adams et al. 1992a) is schematized in Figure 1. Lysogens harboring the plasmid pJ B3.5d were grown at $30^{\circ} \mathrm{C}$ in LB with 50 $\mu \mathrm{g} / \mathrm{ml}$ of ampicillin. At a cell density of 70 Klett units, cultures were shifted to $43^{\circ} \mathrm{C}$ to inactivate the temperature-sensitive $\lambda$ repressor (cl) and induce Int expression. After 10 min with shaking, cultures were returned to $30^{\circ} \mathrm{C}$ because Int is not active at $43^{\circ} \mathrm{C}$. N orfloxacin was added to inhibit the parC ${ }^{+}$and/or gyrA ${ }^{+}$ containing cells when the cultures were shifted to $30^{\circ} \mathrm{C}$ (Bliska and Cozzarelli 1987). Samples $(1.9 \mathrm{ml})$ were removed at various times during the incubation, immersed in liquid nitrogen, stored at $-80^{\circ} \mathrm{C}$, and thawed on ice (Zechiedrich and Cozzarelli 1995). Plasmid DNA was isolated by the alkaline lysis procedure (Sambrook et al. 1989), treated with RN ase A, and divided into two parts. One part was nicked with DN ase I and separated by high resolution electrophoresis on agarose gels (Sundin and Varshavsky 1981). The remaining portion of supercoiled plasmids was analyzed by el ectrophoresis through $1.2 \%$ agarose gels (TAE) with $0,2,4$, or $8 \mu \mathrm{g} / \mathrm{ml}$ of chloroquine. DN A in the gels was transferred to $\mathrm{N}$ ytran membranes and probed with label ed nick-translated pJB3.5d. The Southern blots were exposed to Kodak XAR film or Phosphorlmager (Molecular Dynamics) cassettes for various times (15 $\mathrm{min}$ to $18 \mathrm{hr}$ ). The amount of radioactivity in each band was determined by Phosphorlmager analysis.

For the catenane turnover shown in Figure 7 for a parC $\mathrm{C}^{\mathrm{K} 84}$ gyrA $^{+}$strain, we assumed that all unlinked circles came from catenanes (100\%), as we never observed more than a few percent of catenanes in this strain.

\section{Resolvase recombination}

The assay used for resolvase recombination was as described (Bliska et al. 1991) and is depicted in Figure 8. Cells harboring
pJBRESCl and pRR51 were grown at $30^{\circ} \mathrm{C}$ to a density of $70 \mathrm{Klett}$ units in LB with $30 \mu \mathrm{g} / \mathrm{ml}$ of chloramphenicol, $50 \mu \mathrm{g} / \mathrm{ml}$ of ampicillin, and $15 \mu \mathrm{g} / \mathrm{ml}$ of tetracycline. The cells were shifted to $43^{\circ} \mathrm{C}$ (time $=0$ ) to induce resolvase expression. Cultures were shaken for up to $10 \mathrm{~min}$ at $43^{\circ} \mathrm{C}$. To block decatenation of resolvase recombination products, norfloxacin was added 140 sec after the upshift. This time for drug addition gave a maximal ratio of catenanes to free circles (data not shown). Aliquots (1.9 $\mathrm{ml}$ ) were removed before upshift and at various times after shift to $43^{\circ} \mathrm{C}$. Plasmids were isolated and analyzed as described above.

\section{Acknowledgments}

We thank E.L. Beal I, D.B. Roth, and members of the laboratory for critical reading of the manuscript and C.A. Gross and S. $\mathrm{N}$ akamura for strains. This work was supported by $\mathrm{N}$ ational Institutes of Health grant GM 31657 and National Institute on Environmental Health Sciences grant ESO 1896. E.L.Z. is a Special Fellow of the Leukemia Society of America.

The publication costs of this article were defrayed in part by payment of page charges. This article must therefore be hereby marked "advertisement" in accordance with 18 USC section 1734 solely to indicate this fact.

\section{References}

Adams, D.E., J.B. Bliska, and N.R. Cozzarelli. 1992a. Cre-lox recombination in E. coli cells: Mechanistic differences from the in vitro reaction. J. Mol. Biol. 226: 661-673.

Adams, D.E., E.M. Shekhtman, E.L. Zechiedrich, M.B. Schmid, and N.R. Cozzarelli. 1992b. The role of topoisomerase IV in partitioning bacterial replicons and the structure of catenated intermediates in DN A replication. Cell 71: 277-288.

Belland, R.J., S.G. Morrison, C. Ison, and W.M. Huang. 1994. Neisseria gonorrhoeae acquires mutations in analogous regions of gyrA and parC in fluoroquinolone-resistant isolates. Mol. Microbiol. 14: 371-380.

Benjamin, K.R., A.P. Abola, R. Kanaar, and N.R. Cozzarelli. 1996. Contributions of supercoiling to Tn3 resolvase and phage mu gin site-specific recombination. J. Mol. Biol. 256: 50-65.

Bjornsti, M .-A. 1991. DN A topoisomerases. Curr. O pin. Struct. Biol. 1: 99-103.

Bliska, J.B. 1990. "Studies on site-specific recombination, DN A structure and DNA metabolism in vivo" Ph.D. Thesis, University of California, Berkeley, CA.

Bliska, J.B. and N.R. Cozzarelli. 1987. Use of site-specific recombination as a probe of DN A structure and metabolism in vivo. J. Mol. Biol. 194: 205-218.

Bliska, J.B., H.W. Benjamin, and N .R. Cozzarelli. 1991. Mechanism of Tn3 resolvase recombination in vivo. J. Biol. Chem. 266: 2041-2047.

Bochner, B.R., H.C. Huang, G.L. Schieven, and B.N. Ames. 1980. Positive selection for loss of tetracycline resistance. J. Bacteriol. 143: 926-933.

Chen, C.R., M. Malik, M. Snyder, and K. Drlica. 1996. DNA gyrase and topoisomerase IV on the bacterial chromosome: Quinolone-induced DNA cleavage. J. Mol. Biol. 258: 627637.

Cook, D.N., D. Ma, N.G. Pon, and J.E. Hearst. 1992. Dynamics of DNA supercoiling by transcription in E. coli. Proc. Natl. Acad. Sci. 89: 10603-10607.

de Boer, P.A. 1993. Chromosome segregation and cytokinesis in bacteria. Curr. Opin. Cell Biol. 5: 232-237. 
Dean, F., M.A. Krasnow, R. Otter, M.M. Matzuk, S.J. Spengler, and N.R. Cozzarelli. 1983. Escherichia coli type-1 topoisomerases: Identification, mechanism, and role in recombination. Cold Spring Harbor Symp. Quant. Biol. 47: 769-777.

DiGate, R.J. and K.J. Marians. 1988. Identification of a potent decatenating enzyme from Escherichia coli. J. Biol. Chem. 263: 13366-13373.

- - 1989. M olecular cloning and DN A sequence analysis of Escherichia coli topB, the gene encoding topoisomerase III. J. Biol. Chem. 264: 17924-17930.

DiN ardo, S., K.A. Voelkel, R. Sternglanz, A.E. Reynolds, and A. Wright. 1982. Escherichia coli DNA topoisomerase I mutants have compensatory mutations in DNA gyrase genes. Cell 31: 43-51.

Drlica, K. 1984. Biology of bacterial deoxyribonucleic acid topoisomerases. Microbiol. Rev. 48: 273-289.

Ferrero, L., B. Cameron, B. Manse, D. Lagneaux, J. Crouzet, A. Famechon, and F. Blanche. 1994. Cloning and primary structure of Staphylococcus aureus DNA topoisomerase IV: A primary target of fluoroquinolones. Mol. Microbiol. 13: 641653.

Filutowicz, M. and P. Jonczyk. 1983. The gyrB gene product functions in both initiation and chain polymerization of Escherichia coli chromosome replication: Suppression of the initiation deficiency in gyrB-ts mutants by a class of rpoB mutations. Mol. \& Gen. Genet. 191: 282-287.

Free, A. and C.J. Dorman. 1994. Escherichia coli tyrT gene transcription is sensitive to DN A supercoiling in its native chromosomal context: Effect of DNA topoisomerase IV overexpression on tyrT promoter function. Mol. Microbiol. 14: 151-161.

Gangl off, S., J. M CDonald, C. Bendixen, L. Arthur, and R. Rothstein. 1994. The yeast type I topoisomerase Top3 interacts with Sgs1, a DN A helicase homolog: A potential eukaryotic reverse gyrase. Mol. Cell. Biol. 14: 8391-8398.

Gellert, M. 1981. DNA topoisomerases. Annu. Rev. Biochem. 50: 879-910.

Guarneros, G. and H. Echols. 1973. Thermal asymmetry of sitespecific recombination by bacteriophage lambda. Virology 52: 30-38.

Heisig, P. 1996. Genetic evidence for a role of parC mutations in development of high-level fluoroquinolone resistance in Escherichia coli. Antimicrob. Agents Chemother. 40: 879885.

Heisig, P. and B. Wiedemann. 1991. Use of a broad host-range gyrA plasmid for genetic characterization of fluoroquinoIone-resistant gram-negative bacteria. Antimicrob. Agents Chemother. 35: 2031-2036.

Hiasa, H. and K.J. Marians. 1994. Topoisomerase III, but not topoisomerase I, can support nascent chain elongation during theta-type DN A replication. J. Biol. Chem. 269: 3265532659.

Kato, J.-i., Y. Nishimura, M. Yamada, H. Suzuki, and Y. Hirota. 1988. Gene organization in the region containing a new gene involved in chromosome partition in Escherichia coli. J. Bacteriol. 170: 3967-3977.

Kato, J.-i., Y. N ishimura, R. Imamura, H. Niki, S. Hiraga, and H. Susuki. 1990. N ew topoisomerase essential for chromosome segregation in Escherichia coli. Cell 63: 393-404.

Kato, J.-i., H. Suzuki, and H. Ikeda. 1992. Purification and characterization of DN A topoisomerase IV in Escherichia coli. J. Biol. Chem. 267: 25676-25684.

Keller, W. 1975. Determination of the number of superhelical turns in simian virus 40 DNA by gel electrophoresis. Proc. Natl. Acad. Sci. 72: 4876-4880.

Khodursky, A.B., E.L. Zechiedrich, and N.R. Cozzarelli. 1995.
Topoisomerase IV is a target of quinolones in Escherichia coli. Proc. Natl. Acad. Sci. 92: 11801-11805.

Krasnow, M.A. and N.R. Cozzarelli. 1983. Site-specific relaxation and recombination by the $\mathrm{Tn} 3$ resolvase: Recognition of the DNA path between oriented res sites. Cell 32: 13131324.

Kreuzer, K.N. and N.R. Cozzarelli. 1979. Escherichia coli mutants thermosensitive for deoxyribonucleic acid gyrase subunit A: Effects on deoxyribonucleic acid replication, transcription, and bacteriophage growth. J. Bacteriol. 140: 424435.

Kumagai, Y., J.-i. Kato, K. Hoshino, T. Akasaka, K. Sato, and H. Ikeda. 1996. Quinolone-resistant mutants of Escherichia coli DN A topoisomerase IV parC gene. Antimicrob. Agents Chemother. 40: 710-714.

Liu, L.F. and J.C. Wang. 1987. Supercoiling of the DN A template during transcription. Proc. Natl. Acad. Sci. 84: 7024-7027.

Luttinger, A. 1995. The twisted "life" of DNA in the cell: Bacterial topoisomerases. Mol. Microbiol. 15: 601-606.

Luttinger, A.L., A.L. Springer, and M .B. Schmid. 1991. A cluster of genes that affects nucleoid segregation in Salmonella typhimurium. New Biol. 3: 687-697.

Lynch, A.S. and J.C. Wang. 1993. Anchoring of DNA to the bacterial cytoplasmic membrane through contranscriptional synthesis of polypeptides encoding membrane proteins or proteins for export: A mechanism of plasmid hypernegative supercoiling in mutants deficient in DN A topoisomerase I. J. Bacteriol. 175: 1645-1655.

McN airn, E., N. Ni Bhriain, and C.J. Dorman. 1995. Overexpression of the Shigella flexneri genes coding for DNA topoisomerase IV compensates for loss of DN A topoisomerase I: Effect on virulence gene expression. Mol. Microbiol. 15: 507-517.

Menzel, R. and M. Gellert. 1983. Regulation of the genes for E. coli DN A gyrase: Homeostatic control of DNA supercoiling. Cell 34: 105-113.

Miller, J.H. 1972. Experiments in genetics. Cold Spring Harbor Laboratory, Cold Spring Harbor, NY.

N ash, H.A. 1990. Bending and supercoiling of DNA at the attachment site of bacteriophage lambda. Trends Biochem. Sci. 15: 222-227.

Orr, E., N .F. Fai rweather, I.B. Holland, and R.H. Pritchard. 1979. Isolation and characterization of a strain carrying a conditional lethal mutation in the cou gene of Escherichia coli K-12. Mol. \& Gen. Genet. 177: 103-112.

Osheroff, N., E.L. Zechiedrich, and K.C. Gale. 1991. Catalytic function of DNA topoisomerase II. BioEssays 13: 269-273.

Peng, H. and K.J. Marians. 1993. Escherichia coli topoisomerase IV; purification, characterization, subunit structure, and subunit interactions. J. Biol. Chem. 268: 24481-24490.

Pruss, G.J. and K. Drlica. 1982. Escherichia coli DN A topoisomerase I mutants: Increased supercoiling is corrected by mutations near gyrase genes. Cell 31: 35-42.

Raji, A., D.J. Zabel, C.S. Laufer, and R.E. Depew. 1985. Genetic analysis of mutations that compensate for loss of Escherichia coli DN A topoisomerase I. J. Bacteriol. 162: 1173-1179.

Reed, R.R. 1981. Transposon-mediated site-specific recombination: A defined in vitro system. Cell 25: 713-719.

Rybenkov, V.V., A.V. Vologodskii, and N.R. Cozzarelli. 1997. The effect of ionic conditions on the conformations of supercoiled DNA. II. Equilibrium catenation. J. Mol. Biol. 267: 312-323.

Sambrook, J., E.F. Fritsch, and T. Maniatis. 1989. Molecular cloning: A laboratory manual. Cold Spring Harbor Laboratory Press, Cold Spring Harbor, NY.

Schmid, M.B. 1990. A locus affecting nucleoid segregation in 
Salmonella typhimurium. J. Bacteriol. 172: 5416-5424.

Sinden, R.R., J.O. Carlson, and D.E. Pettijohn. 1980. Torsional tension in the DNA double helix measured with trimethylpsoralen in living E.coli cells: Analogous measurements in insect and human cells. Cell 21: 773-783.

Singer, M., T.A. Baker, G. Schnitzler, S.M. Deischel. M. Goel, W. Dove, K.J. Jaacks, A.D. Grossman, J.W. Erikson, and C.A. Gross. 1989. A collection of strains containing genetically linked al ternating antibi otic resistance el ements for genetic mapping of Escherichia coli. Microbiol. Rev. 53: 1-24.

Spengler, S.J., A. Stasiak, and N .R. Cozzarelli. 1985. The stereostructure of knots and catenanes produced by phage $\lambda$ integrative recombination: Implications for mechanism and DNA structure. Cell 42: 325-334.

Springer, A.L. and M.B. Schmid. 1993. Molecular characterization of the Salmonella typhimurium parE gene. Nucleic Acids Res. 21: 1805-1809.

Srivenugopal, K.S., D. Lockshon, and D.R. Morris. 1984. Escherichia coli DN A topoisomerase III: Purification and characterization of a new type I enzyme. Biochemistry 23: 18991906.

Sternglanz, R., S. DiN ardo, K.A. Voelkel, Y. Nishimura, Y. Hirota, K. Becherer, L. Zumstein, and J.C. Wang. 1981. Mutations in the gene coding for Escherichia coli DNA topoisomerase I affect transcription and transposition. Proc. Natl. Acad. Sci. 78: 2747-2751.

Sundin, O. and A. Varshavsky. 1981. Arrest of segregation leads to accumulation of highly intertwined catenated dimers: Dissection of final stages of SV40 DNA replication. Cell 25: 659-669.

Tewey, K.M., T.C. Rowe, L. Yang, B.D. Halligan, and L.F. Liu. 1984. Adriamycin-induced DN A damage mediated by mammalian DN A topoisomerase II. Science 226: 466-468.

Trucksis, M. and R.E. Depew. 1981. Identification and localization of a gene that specifies production of Escherichia coli DN A topoisomerase I. Proc. Natl. Acad. Sci. 78: 2164-2168.

Ullsperger, C. and N.R. Cozzarelli. 1996. Contrasting enzymatic activities of topoisomerase IV and DN A gyrase from Escherichia coli. J. Biol. Chem. 271: 31549-31555.

Ullsperger, C.J., A.A. Vologodskii, and N.R. Cozzarelli. 1995. Unlinking of DNA by topoisomerases during DN A replication. In Nucleic acids and molecular biology (ed. D.M.J. Lilley and F. Eckstein), pp. 115-142. Springer-Verlag, Berlin, Germany.

Wang, J.C. 1984. DNA supercoiling and its effects on the structure of DNA. J. Cell. Sci. [Suppl.] 1: 21-29.

- - 1985. DNA topoisomerases. Annu. Rev. Biochem. 54: 665-697.

- — . 1991. DNA topoisomerases: Why so many? J. Biol. Chem. 266: 6659-6662.

- - 1996. DNA topoisomerases. Annu. Rev. Biochem. 65: 635-692.

Wasserman, S.A. and N.R. Cozzarelli. 1986. Biochemical topology: Applications to DNA recombination and replication. Science 232: 951-960.

Wasserman, S.A., J.H. White, and N.R. Cozzarelli. 1988. The helical repeat of double-stranded DNA varies as a function of catenation and supercoiling. Nature 334: 448-450.

Watt, P.M. and I.D. Hickson. 1994. Structure and function of type II DN A topoisomerases. Biochem. J. 303: 681-695.

Yamagishi, J.-I., T. Kojima, Y. Oyamada, K. Fujimoto, H. Hattori, S. Nakamura, and M. Inoue. 1996. Alterations in the DNA topoisomerase IV grlA gene responsible for quinolone resistance in Staphylococcus aureus. Antimicrob. Agents Chemother. 40: 1157-1163.

Yoshida, H., T. Kojima, J.-i. Yamagishi, and S. N akamura. 1988.
Quinolone-resistant mutations of the gyrA gene of Escherichia coli. Mol. \& Gen. Genet. 211: 1-7.

Zechiedrich, E.L. and N.R. Cozzarelli. 1995. Roles of topoisomerase IV and DNA gyrase in DNA unlinking during replication in Escherichia coli. Genes \& Dev. 9: 2859-2869. 


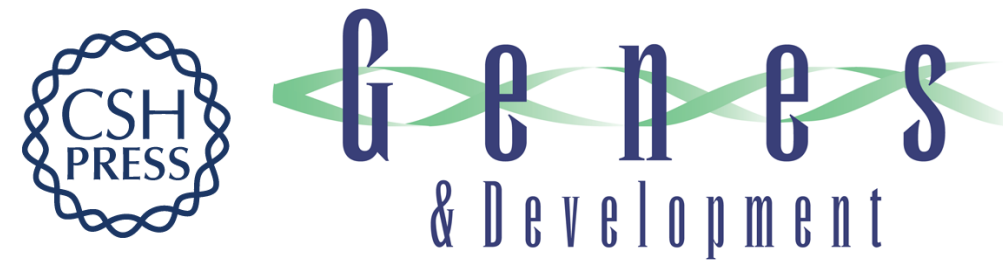

\section{Topoisomerase IV, not gyrase, decatenates products of site-specific recombination in Escherichia coli}

E. Lynn Zechiedrich, Arkady B. Khodursky and Nicholas R. Cozzarelli

Genes Dev. 1997, 11:

Access the most recent version at doi:10.1101/gad.11.19.2580

References This article cites 63 articles, 30 of which can be accessed free at: http://genesdev.cshlp.org/content/11/19/2580.full.html\#ref-list-1

License

Email Alerting Receive free email alerts when new articles cite this article - sign up in the box at the top Service right corner of the article or click here.

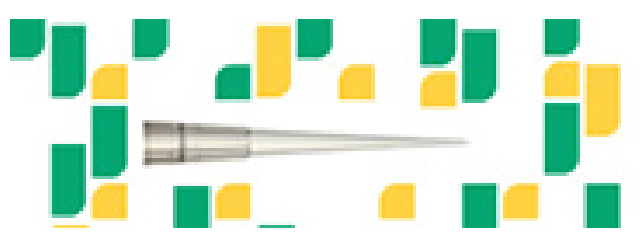

Focused on your science. 